\title{
Skill Development Policies in India: Implications and Challenges
}

\author{
Harshil Sharma \\ CISLS, JNU, India \\ harshilsharma0907@gmail.com
}

\begin{abstract}
India which is moving through 'demographic dividend' and wants to achieve tag of 'knowledge based economy' need to invest in skill formation and developing educated and skilled workforce. This article will begin by broad overview of education and critical evaluation of current skill development policies at school and vocational level. There would be a brief discussion on role played by private sector in training of workforce in India and what are challenges faced by employers and employees and where lies the conflict of interest. After that in concluding section the major problems will be combined together to come out with the broad basic reason for the failure of such policies and conclude by scrutinizing what can be done in future to bridge the gap between educated and employed. Policy approach to skill development is supply driven and less attention is paid to demand side factors. Study recommends creating national training funds which can be used to collect levies from organized and large firms to be used for skill development of the informal sector. Levy based financing can help in solving problem of free rider and moral hazard as is held by the private sector. Study also recommends making vocational education compulsory from 8th standard and bridging the wide gap that exists in Indian labor market between 'educated' and 'employable'.
\end{abstract}

Keywords: Skill Formation, Skill Development Policies, Education system, Private Financing, Vocational Education

\section{Introduction}

Overview of Skill Development System of India: For India, which is moving through 'demographic dividend' and wants to achieve tag of 'knowledge based economy', it then becomes all the more important to invest in improving skills and invest in technologies complementing the respective skills suitable for emerging economic environment. According to a study done by Boston Consulting group, India would have a surplus labor of 47 million by 2020 that is at the same time when there will be shortage of 56 million workforce in the rest of the world (BCG, 2007) The challenge that lies in front of policy makers is to train this large young population to gain productive and meaningful employment to gain a decent standard of living (Pilz, 2015). Skill Development is the answer to the problems of India but unfortunately according to UN in India less than one tenth of labor force has any vocational training (This includes both formal as well as informal training) (ILER, 2014). Even those who are trained are not able to secure employment. Policy approach to skill development is supply driven and less attention is paid to demand side factors ( (Singh, 2003); (Mehrotra, 2014);(Berman, Somnathan, \& Tan, 2005)). To understand the same, it is important to note what is the meaning of the abstract term 'skill' and analyze link between education, skill and unemployment.

'Skill' means any marketable expertise however acquired, irrespective of whether marketed or not, or whether the intention is to market it or not (NSSO, 2013). Skill is broadly defined as a learned ability of an individual to carry out a set of pre-determined task(Srivastava, 2008). There is a misconception in India and many developing countries regarding skill development that skill formation refers only to vocational education. There are 3 type of skills ((Srivastava, 2008) (Mehrotra, 2014)(World Bank, 2012)):

a) Academic/Foundational/Cognitive Skills- basic abilities to read and write which are learnt in school or sometimes through informal means.

b) Transversal/Problem Solving Skills- These are the skills that belong to a particular occupation and can be transferred from one person to another. Ex-soft skills, communication, coordination and team skills c) Technical/ Vocational Skills- job specific skills which are founded upon the first two of the above skills.

Skill Education should not be restricted to vocational training and is a much broader term that includes in its domain education that an individual attains. For the same it is important to analyze the level of education of workforce of our India. 
Table 1: percentage share of total workforce in India at respective education levels in 2011-12

\begin{tabular}{|c|c|c|c|c|c|}
\hline $\begin{array}{l}\text { Average Years of } \\
\text { Education } \\
\text { completed }\end{array}$ & Grade & Qualification and percent & age of workforce in 2011-12 & & \\
\hline 18 & PG & $\begin{array}{l}\text { Post graduate and above- } \\
2.53\end{array}$ & $\begin{array}{l}\text { Science (0.58) Non Science } \\
(1.95)\end{array}$ & & \\
\hline 16 & UG & Graduate- 6.82 & $\begin{array}{l}\text { Science }(2.7261) \\
\text { Non Science }(4.0939)\end{array}$ & & \\
\hline 13 & $\begin{array}{l}\text { 11th- } \\
\text { 12th }\end{array}$ & Senior Secondary- 6.14 & Polytechnic ( 3 years)- 0.48 & $\begin{array}{l}\text { CTS and } \\
2.26\end{array}$ & ATS $^{1-}$ \\
\hline 11 & $\begin{array}{l}\text { 9th- } \\
\text { 10th }\end{array}$ & General Secondary-12.26 & vocational secondary- 0.02 & & \\
\hline 9 & 6th-8th & Middle-17.48 & & & \\
\hline $0-6$ & $\begin{array}{l}\text { 1st } \\
5 \text { th }\end{array}$ & Up to Primary- 22.32 & & & \\
\hline
\end{tabular}

Not literate-28.73

Source: Computed with help of (Mehrotra, 2014),(IMA, 2017), (GOI, 2013)and (AICTE, 2012)

${ }^{1}$ CTS- Craftsmen Training Scheme, ATS- Apprentice Training Scheme

Education condition in India is one of the worst as NSSO data conforms that around 68\% of Indian workforce is less than $8^{\text {th }}$ pass $(28 \%$ - illiterate, $22 \%$ - below primary and $17 \%$-middle) (NSSO, 2013). When elementary education is not completed by majority of population and current skill development system in most training programs does not allow people under $8^{\text {th }}$ class to participate in skill training program then the failure of such programs in inevitable. Number of graduates and above have increased from 23.6 million in 2001 to 33.3 million in 2005 to further 50.5 million in 2010 but employment opportunities for the same are not rising at the same pace. According to current training capacity around 5 million workers are trained per year but the requirement is of around 20 million workers to be skilled every year (Mehrotra, 2014). Current statistics show that roughly $3 \%$ of Indian labor workforce receives any sort of formal training where around every year 12 million workers are added to the workforce (Ernst and Young, 2011). In countries like Korea, Japan, Germany, around $85 \%$ of workforce in the age group of 18-25 have received some form of vocational training and the same figure in case of India drops down to 5\% (Planning commission, 2008). Reasons cited for this are lack of monetary investment but in reality from past many years Union budget have allocated ample resources for production of skilled workforce but the problem has been the inefficient utilization of those resources. Around 21 ministries carry out skill development work even when it is not their expertise (MSDE, 2016).

Skill development programs have always been running behind numbers which started when it was set that by 2022 India would train 500 million workers. (Mehrotra, gandhi, \& sahoo, 2013)argued that the set target was unrealistic and not backed by any empirical evidence and was a gross over estimation. The target through the years has kept on revising itself until Rajiv Pratap Rudy (now ex- minister of Skill Development and Entrepreneurship) abandoned the target even when new target in MSDE policy 2015 was skilling 400 million workers but that target is now kept in policy maker's minds. Skill development policies in India are incremental rather than institutional or transformational. Only focusing on creation of skilled workforce and not having corrections on demand side constraints is an attempt to correct macro policy distortions through micro interventions. This would result only in overcrowding and bumping out of low skilled workers but leave the economy with a large pool of unemployed skilled as well as unskilled workers (Singh, 2003). 
Focus on skill development policies is assumed to have gained prominence among policy makers around the period of 2006-07 and it continues to be a major topic of debate i.e. how to produce 'skilled' as well as 'educated' workforce. In reality general and vocational education has been discussed at length in India through various committee and policy reports. This article will discuss the same in forthcoming section and that would be followed by discussion on school and secondary level vocational education. After that performance of ITIs and other senior secondary and graduate level skill development programs would be taken into account. Due to large level informal unemployment and around 68\% workforce being either illiterate or less than $8^{\text {th }}$ pass there are various informal sector skill development programs which will be taken into consideration in the fourth section. There would be a brief discussion on role played by private sector in training of workforce in India and what are challenges faced by employers and employees and where lies the conflict of interest. After that in concluding section the major problems will be combined together to come out with the broad basic reason for the failure of such policies and conclude by scrutinizing what can be done in future to bridge the gap between educated and employed.

\section{Critical Evaluation of Prevailing Skill Development Policies}

School level skill Education: Till the year 2013 children did not have any opportunity to acquire vocational education until they completed at least schooling at general academic level i.e. till class 10th. Foundational courses at preparatory level can prove to be stepping stone for success in skill development as is case with countries like China, Germany and Korea (Nayantara \& Kumar, 2015). Dropout rate after $10^{\text {th }}$ is very high in India due to socio economic conditions and low returns to education, so it is important to offer education which is in tandem with the world of work (Khare, 2015).When elementary education is not completed by majority of population and current skill development system in most training programs does not allow people under $8^{\text {th }}$ pass to participate in skill training program then the failure of such programs in inevitable. Skill shortage will continue as long as secondary school system does not vocationalize which can make TVET (Technical and Vocational Education and Training) more aspirational.

Private sector participation is negligible at school level formation of curriculums and due to strong mismatch between training provided and needs of private sector, the whole process remains obsolete and of no use to the students.

ITI's: Most prominent way of providing skill training in India are the Government it is and Private ITIs (Which were earlier known as ITCs). There are Centers of Excellence (COE) formed which are expected to create multi-skilled craftsmen with better employability skills. Most of ITI courses require entry qualification of $10^{\text {th }}$ or $12^{\text {th }}$ class which makes over $50 \%$ of workforce not qualified for this system.

Table 2: Total number of functioning ITIs and seating capacity till December 2016

\begin{tabular}{|c|c|c|c|}
\hline Characteristic & Government ITIs & Private ITIs & Total \\
\hline $\begin{array}{lll}\text { Functioning } & \text { ITIs } & \text { till } \\
\text { December 2016 } & \end{array}$ & 2150 & 11200 & 13350 \\
\hline Seating capacity & 713245 & 2134085 & 2847330 \\
\hline
\end{tabular}

Source: MSDE Annual Report (2017)

Percentage of functioning for government ITI is $17.5 \%$ and the same for Private ITI is $82.5 \%$ and this gap is consistently rising according to recent trends. One should not be swayed into positivity by rise in number of private institutions through skill India mission as the trouble lies in the actual functioning of the institutes and their very low IT intake. ITIs spend almost $90 \%$ of their allotted in salaries of the workers of the institute which leaves very less support to maintenance and up gradation of facilities and other operational expenses (Khare,2015). According to a study, (Mehrotra, 2014)found that major problems related to ITIs are that placement is low, dropout rate is high, instructors are not well qualified and draw a very low salary and actual staff strength was less than the sanctioned posts. Comparing government and Private ITIs, it was observed that government owned ITI had more classrooms and practiced more trades but placement was better in private ITIs. People who got trained $67 \%$ had household income of less than Rs. 5000 . Around $60 \%$ teachers themselves are ITI graduates and under qualified to teach. Knowledge and skill of laborer not at par with new technology. Crafts Instructor training scheme (CITS) was introduced in 1948 for training of trainers 
but the scheme did not work efficiently. Only $40 \%$ of 55000 TVET instructors have undergone instructor training course (Ajithkumar, 2015).One of the major reasons among youth of not opting for ITIs are that there is neither job mobility nor enhancement of skills.

\section{Role of Private Sector}

Public private partnership (PPP) in skill development Programs is taken up as a business opportunity and often fully funded by the government which leads to high level inefficiency. Private industries don't want to get involved in funding of the skill training of individuals due to the problems of free rider and moral hazard. (repeat). Planning Commission task force have recommended that skill training should be market linked and demand led (2001) but problem remains with funding of such programs (Srivastava, 2008).Worker qualification in the degree he has attained and the work he/she has to do in the market here is highly mismatched. After liberalization measures were adopted the impact of globalization was thought to positively affect the labor abundant country to adopt labor intensive technologies and foster economic growth leading to large scale employment opportunities. Contrary to the belief, due to large scale competition and high quality standards, the employers are forced to cut labor cost and job-security protection which has hampered the labor market. Also the quality of goods has improved but quality of employment has deteriorated further as there is more employment created in informal and unorganized sector.(Rosenberg, 1976). New and improved technologies are adopted in labor process only when more labor power can be extracted from Alburtis is in contradiction to the conventional notion that the skill complimentary technologies will be adopted. If the capitalist finds other methods to extract higher labor power from workers, then new technology would not be adopted. These methods of extraction of more labor power are large scale flexibilization, outsourcing, formal-informal organization nexus, hire and fire policy, relaxation of labor laws etc. All these methods help in more extraction of labor power and relative to technology and skill advancement seem a better alternative for capitalist to increase profit. Presence of skill premium is already in question and through above argument it can be established that technological changes do not happen due to demand and supply of skilled workforce. Now for the above argument to work there is a need for unlimited supply of labor force and involuntary unemployment as well as they would help in acting as balancing force over the demand driven forces to not affect levels of profits. If there are not enough labor interested to work at given wage then the capitalist would have to look for other methods to increase profits but in a country like India where there is unlimited supply of labor and large involuntary unemployment here the argument works perfectly(Roy, 2012).Private sector does not have a conflict of interest if it gets trained workers but there is a certain power relation among the Indian capitalist class which does not want the population to be skilled and educated which is necessary for their suppression.

\section{Challenges towards Education and Skill Development}

Bureaucratic hurdles, lack of coordinated action between center and state government, lack of on-the-ground initiatives and poor execution has worsened the skill development policies situation in India. Indian work force is dominated by casual workers and many avenues for availing job drawing skills are not available for casual workers. Different Indian states are at different regional demographic and levels of development. 'One size fits all' policy for skill development has not lead to much success in Indian scenario. 


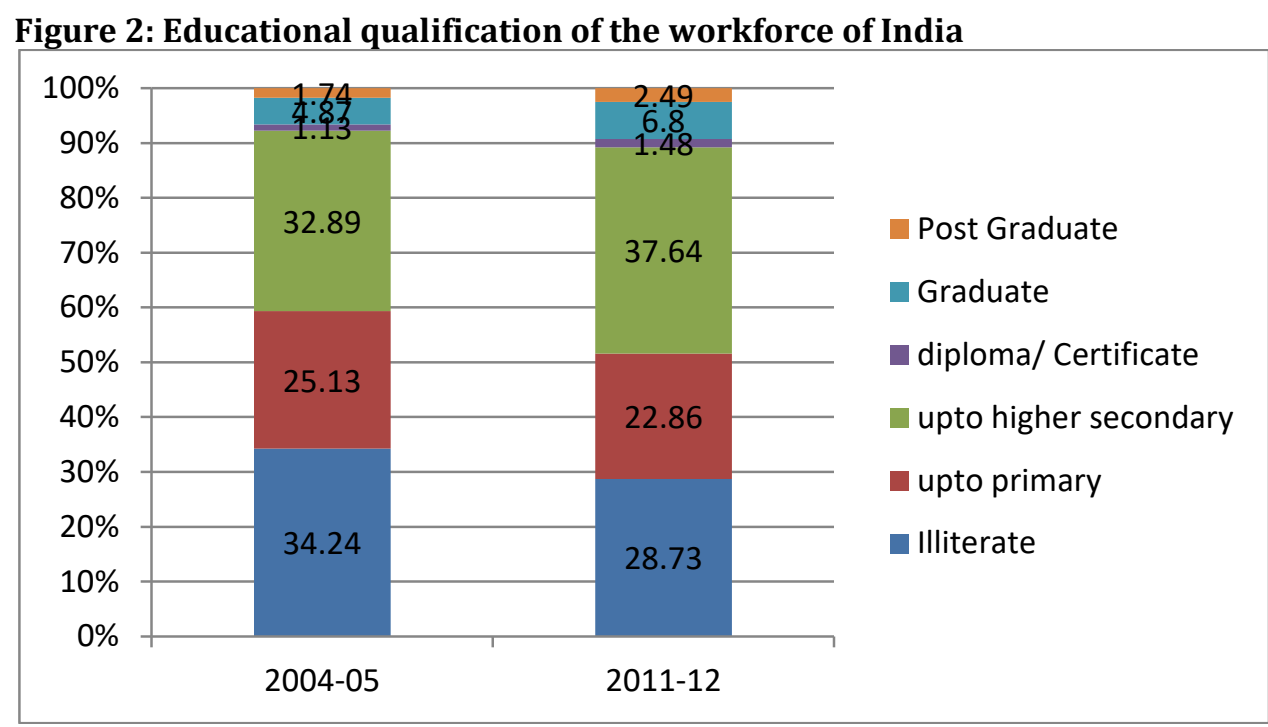

Source: (IMA, 2017)

Now both the arguments have their own advantages and disadvantages but which should be focused more by an economy is a question to be asked. These aspects should be studied as to what kind of a labor a capitalist system prefers so that we can understand which perspective is more dominant. Capitalist system does not prefer a system of education where people are supposed to think alternative lifestyles that don't cater the needs of capitalism(Unni \& Rani, 2008). What to be taught and how it benefits the production process is main aim of the system and any resilience against this system is subdued. In case of Indian economy, higher education researches have been neglected to a very large extent in both the fields of policy and inclusive development. Creating more and more secondary education attained and graduates is the purpose and returns to those educations are still not available in the market due to which we have a large section of skilled educated unemployed.

Indian Economy can either try to adapt to this change and produce a skilled labor force which can meet their own as well as global needs or they can let the continual exploitation of the informal economy by exploiting and feeding on the wage rate and continual falling of labor cost where size of our labor force will grow but their capabilities and standard of living will continue to perish (Robalino \& Almeida, 2012). Another aspect that needs to be analyzed is the strong linkage between skilled workers and unemployment. Focusing on creation of more skilled laborers alone and not having correction of demand side constraints is an attempt to correct macro policy distortions through micro interventions. When a great number of skilled laborers are unemployed and the ones employed are withdrawing a very low salary, the argument of educational attainment leading to better jobs and high wages becomes questionable. What should be the motivation behind a person who may complete his secondary education or graduation to study more if it does not lead to better wages. High demand of skills and relative shortage of skilled workforce may be true in case of a few sectors but in a country like India overall where there is high degree of involuntary unemployment in both skilled as well as unskilled workforce, then the demand and supply of skills is determined by relative absorptive capacity of sectors (Satyaki, 2008). If a skilled worker is not able to realize the price of his labor power, it means it has only intrinsic and not extrinsic labor power. Even though the skill is marketable but does not fetch exchange value till the skill is put to use (Singh, 2003).

\section{Recommendations and Thinking about Future}

One of the recommendations is to make Vocational education compulsory from $8^{\text {th }}$ standard at school level. Interests and abilities of the individual should be identified through proper diagnostic tests to offer basic specific and suitable courses on particular trade for remaining 5 years of their schooling. Implementation of this approach looks abstract and almost impossible but the implementation flaws are to be addressed through institutions which work towards developing inefficiencies in the system. Even if there are only 10000 
schools but they should be used in training of the large informal workforce. Intervention at school level to create career counsel options where students interact with private players regarding which skills are most desirous in the labor market can help create awareness about the prospects available after acquiring vocational skill (Nayantara \& Kumar, 2015).View that provision of skills should be market linked and demand led and this has been voiced by agencies such as Planning Commission (2008) and MSDE (2016) but the problem remains with funding of such programs. Among developing nations India has lowest investment in skill development.

National training funds can be used to collect levies from organized and large firms to be used for skill development of the informal sector. Several Latin American countries have funds dedicated for employment training. In China after 6 years of Primary Education, vocational education is introduced for 3 years and then for another 2 years vocational education for senior secondary school is decided on the basis of a senior high school entrance examination called Zhongkao (FICCI, 2015).Advantage Chinese system has over the Indian counterpart is that it is backed by vocational and training law 1996 but still the Chinese system also suffers from the problem of skill demand supply mismatch (Mehrotra, Gandhi, \& Kamladevi, 2015)Germany is advancing from industrial based to knowledge based economy which is driven by technology and innovation with the help of dual system of education. There is an urgent need to take TVET away from traditional concept of manual labor (Mazumdar, 2015). Dual system of education has its own drawbacks. There are a few highly specialized companies who are not able to train apprentices in all areas, training cost is found to be very high by companies and many graduates at time are not able to cope up with specialized rigid training in only a particular field (Pilz, 2012). In case of India there is over regulation by government and sub optimal structuring so private sector needs to shoulder responsibility of development of skills (Venkatram, 2015). Even if trained youth were able to access placement opportunities they could get salary of Rs. 5000-10000 where aim should be to impart training that can fetch salary close to Rs. 30000 . The need to run behind numbers needs to be addressed as training capacity even if increased but does it help in fulfilling the motive of producing trained employees needs to be questioned. Objective of government policies of vocational education should be to fill the gap between educated and employable (MSDE, 2016). So to summarize there are certain solutions recommended by various studies like building a LMIS, adaptation of NSQF and raise qualification of instructors which is at par with international standards. These solutions though attractive don't look feasible in near future and need to be relooked and reconsidered. In the current standing where there is abundant supply of institutions a long term strategy for skill development is needed for educated students which can be fit for work globally(Venkatram, 2015).Revamping the education system cannot be offered as a recommendation as it is practically impossible but steps in making the system more accommodative is needed. Curriculum needs to be work based and link between jobs and education need to be reconnected. Skill agenda is necessary to be put forward as national and global priority.

\section{References}

Acemoglu, D. (2002). Technical change, inequality and the labour market. Journal of economic literature, 2, 772.

Aggarwal, J. (1993). Landmarks in the history of modern Indian education. delhi: Vikas Publishing House Pvt. Ltd.

AICTE. (2012). Annual Report 2011-12. All India Council for Technical Education. New Delhi: Chanderlok.

Ajithkumar, M. (2015). Training of teachers: Institutionalising training and development of academic faculty of TVET Institutions for realising excellence. In M. Pilz, India: preparation for the world of work: Education system and school to work transition. VS ISBN 978-3-658-08502-5.: Springer.

Bank, W. (2012). Skills, Not Just Diplomas Managing Education for Results in Eastern Europe and Central Asia. Washington DC 20433: he International Bank for Reconstruction and Development / The World Bank.

BCG. (2007). Employment and Skill Development. USA.

Berman, E., Somnathan, R. \& Tan, H. W. (2005). Skill biased technological change here yet? Evidence here yet? Evidence from Indian Manufacturing in the 1990's. World Bank Policy Research Working Paper.

Braverman, H. (1974). Labour and Monopoly Capital: The degradation of work in the thirteenth century. New York: Monthly Review Press.

CBSE. (2013). Teacher qualification report. Delhi: CBSE. 
CBSE. (2014). Curriculum and Syllabus. Delhi: CBSE.

Chenoy, D. (2012). Public-Private partnership to meet the skills challenges in India. Technical and vocational education and training.

DSKMAG. (2009). To quote, unquote and requote - 21st Century illiteracy? URL:https://deangroom.wordpress.com/2009/12/21/to-quote-unquote-and-requote-21st-centuryilliteracy/.

Earst, Y. a. (2011). Reaping India's promised demographic dividend- industry in driving seat. Delhi: FICCI.

FICCI. (2015). kill development in India, Konra Adenauer Stiftung. delhi: Federation of Indian Chambers of Commerce \& Industry.

GOI. (2010). The challenges facing skill Development in India: An Issue paper. Delhi: Institute of Applied Manpower Research.

GOI. (2013). Provisional Report on All India Survey for Higher Education 2011-12. New Delhi: Ministry Of Human Resource Development Department Of Higher Education.

GOI. (2014). Education, skill development and labour force. Chandigarh: MOLE.

GOI. (ational Policy On Education 2016, Report Of The Committee For Evolution Of The New Education Policy). 2016. delhi: Government of India.

Goldin, C. \& Katz, L. (1998). The origins of technology-skill complementarity. The quarterly journal of economics, 3, 693-732.

Goos, M. (2013). How world of work is changing. Geneva: ILO.

Hajela, R. (2012). Shortage of skilled workers: A paradox of the Indian economy. SKOPE Research paper University of Oxford.

ILER. (2014). Indian labour employment report: Workers in the era of globalization. Delhi: Institute for human development.

IMA. (2017). The India Employment Report. Powerpoint Presentation. Retrieved from URL: http://www.imaindia.com/pdfs/the-india-employment-report-sample-slides.pdf.

Jha, P. \& Amit, C. (2014). Post-Fordism, Global Production Networks And Implications For Labour: Some Case Studies from National Capital Region, India. Institute for Studies in Industrial Development, Delhi.

Khare, M. (2015). Higher Education / University: Taking the Skills March Forward in India - Transitioning to the World of Work. In M. Pilz, ndia: Preparation for the world of work: Education System and School to work Transition. US: Springer.

Kumar, K. (2015). ITIs / ITCs: Industrial Training Institutes / Industrial Training Centres. In M. Pilz, India: Preparation for the world of work: Education System and School to work Transition. Springer.

Lenin, V. (1918). Lenin's Collected Works. Moscow: Progress Publishers.

Marx, K. (1867). Das Kapital. Delhi: Jainco Publishers.

Mazumdar, S. (2011). Investment and Growth in India under Liberalization: Asymmetries and Instabilities. Delhi: Institute for Studies in Industrial Development.

Mazumdar, S. (2015). Foreword Reflections on Opportunities and Challenges of Skills Development in India. In M. Pilz, India: Preparation for the world of work: Education System and School to work Transition. Springer.

Mehrotra, S. (2014). Indias skills challenge: reforming vocational education and training to harness the demographic dividend. New Delhi: Oxford University Express.

Mehrotra, S. (2016). Realising the demographic dividend: policies to achieve inclusive growth in India. New Delhi: Cambridge University Press.

Mehrotra, S., Gandhi, A. \& Kamladevi, A. (2015). China's Skill Development System : Lessons for India. Economic and Political Weekly, 4(28).

Mehrotra, S., Gandhi, A. \& Sahoo, B. (2013). Estimating India's skill gap on a realistic basis for 2022. Economic and political weekly, 17(13).

MOE. (1966). Education and National Development Report Of The Education Commission, 1964-66. Delhi: National Council Of Educational Research And Training.

Mohanty, J. (2003). Teacher Education. delhi: Deep and Deep Publication.

MSDE. (2016). Report Of The Committee For Rationalization \& Optimization Of The Functioning Of The Sector Skill Councils. Volume 1. New Delhi: Government Of India.

NASSCOM. (2005). Extending India's Leadership of the Global IT and BPO Industries. Mckinsey. 
Nayantara, S. \& Kumar, S. (2015). Primary and Upper Primary (1-8) Education: Initiative for the World of Work at the Primary and Upper Primary Education in India. In M. Pilz, Preparation for the world of work: Education System and School to work Transition. Springer.

NPE. (1986). The National Policy On Education (Npe) 1986. Delhi: MHRD.

NSSO. (2013). Employment and Unemployment Situation in India, Part-II. Delhi: Government Of India.

Pilz, M. (2015). India: Preparation for the world of work: Education System and School to work Transition. In M. Pilz, Introduction. Springer VS. ISBN 978-3-658-08502-5.

Robalino, D., \& Almeida, R. (2012). Overview. In World Bank (2012). The Right Skills for the Job? Rethinking training policies for workers. Washington DC: NewYork Press.

Rosenberg, N. (1976). Perspectives on technology. New York: Cambridge University Press.

Roy, S. (2008). Skill premium: What caused the 'mismatch'? Munich: MPRA, Paper 18010.

Roy, S. (2012). hanging factor incomes in industries and occupations. Delhi: ISID.

Sabharwal, M. (2013). Education, Employability, Employment, and Entrepreneurship: Meeting the Challenge of the 4Es. In Maclean, Skills Development for Inclusive and Sustainable Growth in Developing AsiaPacific. Springer.

Schrembs, R. (2001). Teaching in the TVET System, Basics for Vocational Teachers in DevelopingCountries. Triga Verlag.

Singh, C. (2003). Skill, Education and Employment. Economic and Political Weekly, 3, 31-38.

Srivas, A. (2017). How modi's flagship skill india project stumbled hard in its first year. Retrieved from the wire: URL:https://thewire.in/134440/modi-skill-india-stumbled/

Srivastava, R. (2008). Education, skills and the emerging labour market in India. The Indian journal of labour economics, $51(4)$.

TOI. (2017). Unemployment in India to increase marginally in 2017-18: UN Report. . Retrieved from toi: https://timesofindia.indiatimes.com/india/unemployment-in-india-to-increase-marginally-in-201718-un-report/articleshow/56512962.cms

UNESCO. (2011). Global Monitoring Report. Geneva: World Economic Forum.

Unni, J., \& Rani, U. (2008). Flexibility of labour in globalising India: The challenge of skills and technology. New Delhi: Tulika Books.

Venkatram, R. (2012). Vocational Education and Training System (VET) in India. In M. Pilz, The Future of Vocational Education and Training in a changing world. Springer.

Venkatram, R. (2015). Vocational Education and Training in India. In M. Pilz, India: Preparation for the world of work: Education System and School to work Transition. Springer. 